researches, have shown that only a trifling correction is needed to Gutenberg's early result. It is somewhat invidious to attempt to single out any one topic from the vast array of subjects on which he worked in later years, but mention should be made of the important impact produced on geological and geophysical science by the long series of studies, made jointly with $\mathrm{C}$. F. Richter, of the magnitude and distribution of earth quakes, a work that has given an enormous impetus to the study of the seismicity of the Earth.

Beno Gutenberg was born in Darmstadt on June 4, 1889. His training at the University of Göttingen afforded him the best possible ground-work at that time in the young science of seismology. Already well equipped with a wide and deep pre-university education, he attended mathematical lectures by Hilbert, Klein, Minkowski, Landau, Born, Wiechert and Weyl. In geophysics he worked on microseisms under Wiechert, who indeed covered in his lectures a wide range of geophysical studies. Jointly with Geiger, Gutenberg developed the Z:öppritz method of using the amplitudes of seismic waves to study the internal structure of the Earth, and received his Ph.D. degree in 1911 at the age of twenty-two. After a further year of advanced study, during which he completed his paper on the Earth's core, and a year in the Army, Gutenberg was appointed assistant at the International Seismological Central Station at Strasbourg, which at that time was in Germany. In 1924 he became director of the Feldberg (Taunus) Seismic Observatory of the University of Frankfurt, at which University he later became a professor. During these years, in addition to the heavy load of observation, writing and teaching, he directed the family business inherited from his father.

In 1931 he was appointed professor of geophysics and meteorology in the California Institute of Technology, Pasadena ; here he played a notable part in the development of the Seismological Laboratory, of which he was director from 1947 until his retirement in 1957.

In later years honours fell thick upon him, both from European and from American academies. During 1951-54 he was president of the International Association of Seismology and Physics of the Earth's Tnterior.

Gutenberg was a kindly man, ever ready to help a fellow scientist and to indulge in a scientific tête-à-tête, and his accurate and retentive memory made him a pleasant and interesting companion. Visitors to Pasadena received a warm and hospitable welcome from Prof. and Mrs. Gutenberg ; theirs was indeed a happy and cultured home. Gutenberg had a large collection of records of classical music, and those visitors who shared his taste appreciated the privilege of the musical intimacy that he so freely extended. To the last his powers of original work remained unimpaired; seismologists will mourn the loss not only of a great man but also of a valued friend.

R. STONELEY

\section{Dr. Otto Schindler}

Dr. Otro Schindeer, who died suddenly on September 4 at Poitiers, while on a collecting expedition, had come to occupy a leading position among the small band of European ichthyologists.

$\mathrm{H}_{\theta}$ was born on December 1, 1906, and spent his childhood in Vienna and the Sudetenland. During
1925-30 he studied in Vienna under Versluys and gained his doctorate in 1930 with a thesis on fishery biology. For a short time he worked in the Vienna Museum; but the greater part of his mature work was done at the Zoologische Staatssammlung at Munich, where he attained the rank of Oberkonservator.

At Vienna it fell to his lot to describe two species of small fishes collected by Dr. V. Pietschmann over Hawaiian reefs. Although no more than a couple of centimetres long and showing many larval characters, these fishes included ripe males and females. Dr. Schindler directed attention to their pædogenetic characters, but placed them in the genus Hemirhamphus. When later Giltay found one in New Guinea waters he formed other views on their relationships and created a genus Schindleria and family Schindleriidae for them. More recently, Gosline (1959) made of them a distinct suborder, relating them tentatively, as Giltay did, to the blennies. Schindler himself was stimulated by them to make a comparative investigation of the kidneys of larval marine fishes, for which he paid a special visit to the Plymouth Marine Laboratory to collect material.

Schindler's other fields of interest were the ecology of the freshwater fishes of the Austrian and Bavarian lakes and the fish-fauna of South America. He took part in two expeditions to the latter continent and studied the collections of the early expeditions in Vienna and London. His field book of German freshwater fishes, "Unserer Süsswasserfische" (1953 and 1959), was translated into English and edited in 1957 by Dr. P. A. Orkin.

As a result of Dr. Schindler's initiative and organization the German ichthyologists produced a quarterly "Ichthyologischer Schriftennachweis", a classified list of titles, by which they helped each other to keen abreast of current ichthyological publications. With. out his leadership this and much else in German ichthyology come to an end. All who knew him miss a valued colleague and friend. Frau Dr. Schindler, a scholar in another field, is left to mourn him with their daughter and two sons, the eldest just of university age.

E. Trewayas

\section{Dr. L. O. Kunkel}

Louis OtTo KunkeL, faculty member of the Rockefeller Institute during 1931-49, was actively conducting scientific research in the field of plant pathology at the Institute up to the time of his death. on his farm at Newtown, Pa., on March 20.

Dr. Kunkel established the Division of Plant Pathology at the former Princeton, New Jersey, branch of the Rockefeller Institute in 1931 and influenced significantly the growth of knowledge concerning the relationship of viruses to plant diseases. Bringing to his research theoretical knowledge and practical experience in the United States and Hawaii, he conducted research which shed new light on the nature of the virus and also led to new understanding of disease in peaches and other fruits, cranberries, maize and carrots.

Dr. Kunkel helped to foster the work of his associate, Dr. Wendell M. Stanley, who, in conjunction with Dr. John H. Northrop, shared the Nobel Prize in chemistry in 1946 for crystallizing the tobaceo mosaic virus. Dr. Kunkel, in administering his laboratory, gave his junior associates a free hand in investigating the cause, transmission, pathology, 